Fountain Journal of Natural and Applied Sciences: 2016; 5(1): 12 - 18
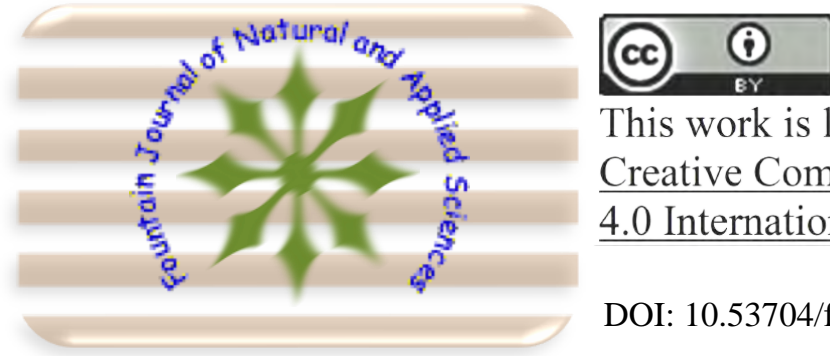

This work is licensed under

Creative Commons Attribution

$\underline{4.0 \text { International License. }}$

DOI: 10.53704/fujnas.v5i1.68

A publication of College of Natural and Applied Sciences, Fountain University, Osogbo, Nigeria.

Journal homepage: www. fountainjournals.com

ISSN: 2354-337X (Online), 2350-1863 (Print)

\title{
Phytochemical, Proximate and Mineral Composition of Gmelina arborea Fruits (White Teek).
}

\author{
${ }^{*}$ Lawal A.T. ${ }^{1}$, Adeoye, M.D. ${ }^{1}$, Abdulazeez A.T. ${ }^{2}$, Azeez, L ${ }^{3}$, Yakubu, A.S. ${ }^{2}$, \\ Mciver F.A. ${ }^{2}$ and Oladimeji A.O. ${ }^{2}$ \\ Department of Chemical Sciences, College of Natural and Applied Sciences, Fountain University, Osogbo \\ ${ }^{2}$ Department of Chemical and Geological Sciences, College of Natural Sciences, Al-Hikmah University, Ilorin, Nigeria, \\ ${ }^{3}$ Department of Chemical Sciences, Osun State University, Osogbo
}

\begin{abstract}
The minerals and nutritional values of leaves, fruits and seeds of many plants have been reported to vary, depending on factors like generic background, location, environmental and cultivation methods. Thus, phytochemical, proximate and mineral compositions of Gamelina arborea ( $G$. aborea ) fruits from Kaduna state in North central part of Nigeria were assessed using standard analytical procedures. Qualitative phytochemical screening revealed that the fruit contained tarnnis, phenols, flavinods, saponins, reducing sugar and anthraquinones. The analysed $G$. aborea contained $7.30 \% \mathrm{w} / \mathrm{w}$ ash, $5.00 \% \mathrm{w} / \mathrm{w}$ moisture, $5.31 \% \mathrm{w} / \mathrm{w}$ fat, $4.30 \% \mathrm{w} / \mathrm{w}$ fibre, $2.00 \% \mathrm{w} / \mathrm{w}$ protein and $75.00 \% \mathrm{w} / \mathrm{w}$ carbohydrate while its mineral compositions $(\mathrm{mg} / 100 \mathrm{~g})$ were shown to contain $\mathrm{Na}(21.70 \pm 1.00)$; $\mathrm{Ca}(29.70 \pm 2.00), \mathrm{K}(14.50 \pm 1.50), \mathrm{P}(10.36 \pm 0.90), \mathrm{N}$ (0.18 \pm 0.00$), C u(9.40 \pm 0.08)$, and $M n(21.70 \pm 1.00)$. Therefore, this finding accounts for the use of G. arborea as supplement for minerals in animal feeds.
\end{abstract}

Key words: Phytochemical, mineral composition, proximate composition, Gmelina arborea

\section{Introduction}

Gmelina arborea, also known as Malina, is the most widely cultivated species of the genus Gmelina in the family Lamiaceae is a well-known medicinal plant in the India and Africa (Sedgley and Gardner, 1990; Conn and Barry, 2001; Hyland, Whiffin and Zich, 2010; Rogier, 2012,). The fruit of the plant is used in treatment of scorpion sting, snake-bites (Nadkarni, 2000) and diabetes (Khan and Khanum,
2005; Kulkarni and Veerajanlu, 2009) and the leaves may be used as forage for livestock which are considered good for cattle and are also used as a feed to Eri silk worm (Kirtikar and Basu, 1999). Akyala, David and Simon (2013) also concluded that

*Corresponding author: +2348131826098

Email address: abdul.lawal@yahoo.com 
Gmelina arborea fruits possess antibacterial activity. This corroborates the rationale for the use of the plant in the treatment of ailments like wounds, sores, burns, vaginal discharges, aphrodisiac, astringent, analgesic, antipyretic, antidiabetic, diuretic, anti-inflammatory in traditional medicine (Lauridens and Kjer, 2002; Shirwaikar and Padma, 2003; Giri and Divakar, 2009; Nayak, Jena, Dinda and Ellaiah, 2011; Akyala, David and Simon, 2013).

The fruits, leaves and seeds extracts of $G$. arborea has been reported by many authors from various locations to contain nutrients, mineral constituents and phytochemicals like alkaloids, steroids, carbohydrates, anthraquinone, glycosides, triterpenoids, saponinns gums, mucilages, tannins, phenolic compounds and flavonoids and proteins (Adegbehin and Abayomi, 1988; Nayak, Jena, Dinda and Ellaiah, 2012). Phytochemicals are bioactive compounds which works with nutrients and dietary fibre to protect against diseases (Sangeeta and Sujata, 2006). They are secondary metabolites that contribute to flavour and colour (Craig, 2009). These compounds have been hypothesized to be responsible for much of the disease protection conferred from diets high in fruits, vegetables, beans, cereals, and plant-based beverages such as tea and wine. They can be classified as phenolic acids, flavonoids and stilbenes/lignans based on their chemical structures. Flavonoids are further divided into anthocyanin, flavones, flavanones, isoflavones, and flavonols, among others (Anjanelu and Jaganmoha, 1975; Arts and Hollman, 2005).

The relevance of phytochemical analysis in plants is to enable detection the non-nutritive chemicals found in plants that may affect health in order to modify their products by suitable biological and chemical means into patent drugs (Guinder and Daljik, 2009). The methods used for the determination of these different non-nutritive chemicals in plants vary according to the plant material being analyzed and in the details of evaluation (Gulcinet et al., 2010).

Also, the minerals and nutritional values of leaves, fruits and seeds of many plants have been reported to vary, depending on factors like generic background, location, environmental and cultivation methods. Therefore, the aim of this study is to investigate the chemical composition, phytochemicals, proximate and moisture content of Gamelina arborea fruit from Kaduna, north-central Nigeria.

\section{Materials and Methods \\ Standards and Reagents}

Standard BHA (butylatedhydroxyanisol), Quercetin, Folin-ciocaiteus, phenol DPPH (2, 2diphenyl-1-picrylhydrzyl) were all purchased from British Drug House limited (BDH), Poole, England. All the chemicals used were of analytical grade. Deionized-distilled water was used throughout the experiment.

\section{Extraction}

The samples were rinsed with distilled water to remove sand, cut into pieces and lyophilized to remove the moisture contents. Resulting dried samples were powdered using Mouling blender. These ground samples were extracted twice with a total volume of $100.0 \mathrm{ml}$ of $70 \%$ aqueous methanol. The mixture was shaken on an orbital shaker for 75 min at $250 \mathrm{rpm}$ and then filtered through Whatman No 1 filter paper. The combined methanolic extract was the evaporated at $55^{\circ} \mathrm{C}$ using water bath and dried to powder in a lyophilizer.

\section{Proximate Analysis}

The proximate analysis of the samples for moisture, total ash, crude fibre, fat were carried out in triplicate in accordance with the methods described by Onwuka (2005). The nitrogen was determined by micro Kdjeldah method (Onwuka, 2005), the nitrogen content was then converted to protein by multiplying with a factor of 6.25 . Total carbohydrate contents were estimated by difference'. All the proximate values were reported in percentage (\%).

\section{Determination of Moisture}

Moisture was determined by oven drying method. $2 \mathrm{~g}$ of well-mixed samples was accurately 
weighed in clean, dried crucible $\left(W_{1}\right)$. The crucible was allowed in an oven at $100-105^{\circ} \mathrm{C}$ for $6-12$ hours until a constant weight was obtained. Then the crucible was placed in the desiccators for $30 \mathrm{~min}$ to cool. After cooling it was re-weighed $\left(W_{2}\right)$ and the percentage moisture was calculated by the formula: $\%$ Moisture $=\mathrm{W}_{1}-\mathrm{W}_{2} \times 100$

Where W

$W_{1}=$ Initial weight of crucible + Sample $W_{2}=$ Final weight of crucible + Sample $W=$ Weight of sample

Determination of Antioxidants and Phytochemicals Antioxidant activity was determined by standard chemical test of DPPH radical scavenging and reducing power assays. A portion of each extract was subjected to standard chemical test for detection of saponins, flavonoids, phenolics, steroids, anthraqunones, and cardiac glycosides using the method described by Harbone (1973) and Odebiyi and Sofowora (1978). Total phenols and flavonoids content were also determined.

\section{Mineral Analysis}

The powdered sample was subjected to nitric acid and perchloric acid digestion (Asaolu, 1995). The minerals (sodium, potassium, calcium, and magnesium) contents in the sample were determined using atomic absorption spectrophotometry.

\section{Determination of Ash}

Clean empty crucible was placed in a muffle furnace at $550^{\circ} \mathrm{C}$ for an hour, cooled in desiccators and then weight of empty crucible was noted $\left(W_{3}\right)$. Two gram of each of sample was put in the crucible $\left(\mathrm{W}_{4}\right)$, and was allowed to charr in the burner. The crucible was then placed in muffle furnace at $550^{\circ} \mathrm{C}$ for 3 hours until the contents in it were ashed. The appearance for gray white ash indicates complete oxidation of all organic matter in the sample. After ashing, the crucible was cooled and re-weighed $\left(W_{5}\right)$. Percentage ash was calculated by the formula: Percentage Ash $=W_{4}-W_{5} / W_{4}-W_{3} \times 100$.

\section{Statistical analysis}

All results are expressed as mean \pm standard deviation. All results are means of three replicates.

\section{Results}

\section{Proximate composition}

The proximate composition as shown in table 1 indicated that the analysed $G$. Aborea contained $2.00 \pm 0.05$ protein, $5.30 \pm 0.08$ fat, $5.30 \pm 0.08$ crude fiber, $\quad 4.30 \pm 0.05$ moisture, $75.90 \pm 2.50$ carbohydrate and ash content of 7.50 \pm 0.09 $\mathrm{mg} / 100 \mathrm{~g}$.

Table 1: Proximate Composition of G. arborea fruit

\begin{tabular}{ll}
\hline Component & $\%$ composition \\
\hline Protein & $2.00 \pm 0.05$ \\
Fat & $5.30 \pm 0.08$ \\
Ash & $7.50 \pm 0.09$ \\
Moisture & $4.30 \pm 0.05$ \\
Crude fibre & $5.00 \pm 0.05$ \\
Carbohydrate & $75.90 \pm 2.50$ \\
\hline
\end{tabular}

Data are means \pm standard deviation of 3 replicates

\section{Mineral composition}

The mineral composition indicates that $G$. arborea contained potassium $(14.50 \pm 1.50)$, sodium $(61.50 \pm 2.00)$, calcium $(29.70 \pm 2.00)$ and manganese $(21.70 \pm 1.00) \mathrm{mg} / 100 \mathrm{~g}$ (Table 2). The results also show that the fruit contain an appreciable amount of phosphorous, copper and potassium (Table 2).

\begin{tabular}{ll} 
Table 2: Mineral Composition of G. arborea fruit \\
\hline Mineral & Composition $(\mathrm{mg} / 100 \mathrm{~g})$ \\
\hline $\mathrm{Ca}$ & $29.70 \pm 2.00$ \\
$\mathrm{Cu}$ & $9.40 \pm .0 .08$ \\
$\mathrm{Mn}$ & $21.70 \pm 1.00$ \\
$\mathrm{Fe}$ & $1.30 \pm 0.03$ \\
$\mathrm{~Pb}$ & $\mathrm{~N} / \mathrm{D}$ \\
$\mathrm{Na}$ & $61.50 \pm 2.00$ \\
$\mathrm{~K}$ & $14.50 \pm 1.50$ \\
$\mathrm{P}$ & $10.36 \pm 0.90$ \\
$\mathrm{~N}$ & $0.18 \pm 0.00$
\end{tabular}

Data are means \pm standard deviation of 3 replicates; N/D - not detected

\section{Phytochemical contents}

The phytochemical screening of $G$. arborea fruit revealed that the fruit contained phytochemicals like phenols, tannin, saponins, flavonoids, alkaloids and anthraquinones (Table 3). 
Table 3: Phytochemical Composition of G. arborea fruit

\begin{tabular}{ll}
\hline Phytochemical & $\%$ Composition \\
\hline Tannins & + \\
Flavonoids & + \\
Saponins & + \\
Terpenes & - \\
Glycosides & - \\
Volatile Oil & - \\
Alkaloids Saponins Glycosides compound/ & + \\
Reducing & + \\
sugar & + \\
Cardiac Glycosides & + \\
Phenols & + \\
Phlobatannins & - \\
Anthracene & - \\
Anthraquinones & + \\
Steroid Carotenoids & - \\
C & - \\
\hline
\end{tabular}

+ = detected; - = not detected

\section{Discussion}

Proximate analysis estimates and determines the major components, i.e. moisture, fats, proteins, ash, crude fiber in a given food (Rajamohamed, 2003). In the Gmelina arborea fruits analysed, carbohydrate has the highest value (75.90\%). This agrees favourably with Aberoumand (2011) who similarly got high carbohydrate contents in fruits of Myrtus communis and Cordia myxa (Hasan et al., 2011). Vunchi et al. (2011) also stressed that, most fruits have high carbohydrate contents depending on the fruit type, maturity and environment. Carbohydrates play several vital roles in living organisms and they can be oxidized to yield energy while their polymers act as energy storage molecules. This result therefore indicates that $G$. arborea is a good source of energy. Protein, which plays vital role in biological processes, is responsible for transportation of molecules, oxygen and messages from cell to cell and keeps human body healthy $(F A O, 1976)$, is relatively low in the analyzed $G$. arborea. The results oppose the findings of Amata (2012) and Omokanye (2014) in the fruits and leaves of $G$. arborea respectively. Ash content is a measure of mineral content of the original food (Onwuka, 2005); this is important in biochemical reactions, functioning as co-enzyme. The appreciable content of ash in $G$ arborea is a reflection that it contained high amount of minerals and a source of dietary minerals. G. arborea will also probably be suitable as a good source of dietary fibre because of its reasonable crude fiber contents. Evidences have shown that consumption of reasonable amount of fiber lowers the risk of coronary heart disease, obesity, bowel cancer and type II diabetes mellitus (Houghton, 2007). Moisture content, an indication of the amount of water present in a sample is low in $G$ arborea; this could hinder the growth of bacteria or any microorganisms and elongate its shelf life.

The presence of potassium in $G$. arborea signifies that potassium plays significant roles in enhancing crop quality, high levels of available potassium improve the physical quality, disease resistance, and shelf life of fruits and vegetables used for human consumption. The absence of detectable level of lead indicates that $G$. arborea is consumable since, lead taken internally in any of its forms is highly toxic. The effects are usually felt after it has accumulated in the body over a period of time. The symptoms of lead poisoning are anemia, weakness, constipation, colic, palsy, and often a paralysis of the wrists and ankles.

Phenolics and flavonoids have been shown to contribute significantly to antioxidant of fruits and vegetables. The test for cardiac glycosides, tannins, and flavonoids, and saponins, saponin glycosides, reducing compound/sugar, phenols and anthraquinones were positive in this analysed fruits sample (Vogel, 2005; Halliwell, 2007; Tiwari and Yadav, 2008). The presence of tannins in the $G$ arborea may be due to the presence of polyphenolic compounds which medically are antidiarrheal and haemostatic compounds (Sofowora, 1983; Foo and Joseph, 1989; Akyala and Davies, 2013). The presence of flavonoids gives a pleasant aroma to the $G$. arborea fruit which is important in the human diet for controlling cholesterol level in the body 
(Haruna, 2008). Saponins were found to be present in the fruit even though it makes the fruit to have stimulating effect. The presence of saponins in the $G$ arborea fruit indicate that the fruit can be used as antibacterial and antimicrobial agent (Sofowora, 1983). Phenols in the sample also indicate its usage in the manufacture of resins, plastics, insecticides, explosives, dyes, and detergents, and as raw material for the production of medicinal drugs such as aspirin.

Glycosides are also found to be absent in the fruit. These are bitter tasting, and it is believed that they help keep birds and insects from eating seeds and fruit of this plant before they are fully grown, by which time the glycosides have been converted to sweet sugars. G. arborea contain phenols, which are strong antioxidants that prevent oxidative stress/oxidative damage to DNA, lipids and proteins that play roles in prevention of diseases such as cancer and cardiovascular diseases (Satyanarayana and Kasai, 1985; Hosny and Gemelinoside, 1998).

The study conducted by Nayak et al. (2012) revealed that this fruit contains cardiac glycosides and steroids which are similar with the outcome of our present study. The ethanol extract contains alkaloids, carbohydrates, anthraquinone glycosides, gums, mucilages, tannins, phenolic compounds and flavonoids. The ethyl acetate extract contains gums, mucilages, proteins and amino acids. The $n$-butanol extract contains alkaloids, anthraquinone glycosides, gums, mucilages, tannins, phenolic compounds, triterpenoids, saponins and flavonoids. The petroleum ether extract contains alkaloids, carbohydrates, anthraquinone glycosides, proteins, amino acids, triterpenoids and saponinns (Nayak et al., 2012). From the research conducted by ElMahmood (2010), phytochemical screening of the Gmelina arborea revealed the presence of carbohydrates, alkaloids, saponins, tannins, anthraquinones and cardiac glycosides which shows some similarities with our present study.

\section{Conclusion}

The phytochemical, proximate and mineral composition of Gmelina Arborea were assessed. This study shows that Gmelina Arborea could be a good source of potassium, and a good diet for the diabetics because of the high potassium/sodium ratio, $\mathrm{K} / \mathrm{Na}$ (25:1) and also a source of carbohydrate and mineral $(75.9 \%$ of carbohydrate and $7.5 \%$ of ash). The phytochemical studies of the fruit serve as a lead in establishing the active ingredient in the fruit. The proximate composition of the fruit show the fruit is a good source of healthy food good for human consumption.

\section{References}

Aberoumand, A. (2011). Preliminary evaluation of some phytochemical and nutrients constituents of Iranian Cordia myxa fruits. International Journal of Agricuture and Food Scince. 1(2): 30-33.

Adegbehin, J.O, Abayomi, J. O, Nwaigbo, L. B. (1988). Gmelina arborea in Nigeria. Commonwealth Forestry Review 67(2), 15966.

Akyala I. A, David, I. \& Simon I. (2013). Phytochemical screening and antibacterial activity of Gmelina arborea fruit extracts. International Journal of Microbiology and Immunology Research 1(2): 26-31.

Amata, I. A. (2012) Comparative evaluation of the amino acid and mineral content of the fruit Gmelina Arborea tree during growth and development. International Journal of Plant, Animal and Environmental Science2,264269

Anjali, S. \& Sheetal, S. (2013). Phytochemical Analysis and Free Radical Scavenging Potential of Herbal and Medicinal Plant Extracts. Journal of Pharmacognosy and Phytochemistry 2013; 2 (4): 22-29.

Anjaneyulu, A.S, Jaganmohan, R.K, Kameshwara, R.V, Ramchandra, R.L, Subrahmanyam, C, Pelter, A. (1975). The structure of lignans from Gmelina arborea Linn. Tetrahedron 31(1), 1277

Arts, I.C. and P.C. Hollman, Polyphenols and disease risk in epidemiologic studies. America Journal of Clinical Nutrution, 2005. 81(1) 
317S-325S.

Asaolu(1995) Lead content of vegetables and Tomatoes at Erekesan market, Ado Ekiti. Pak, Journal of Industrial.Research.38,399400

Ben, S. H., Atti, N., Prilo, A and Nefzauoi, A. (2002). Polyethylene glycol in concentrate or feed blocks to deactivate condensed tannins in Acacia cyanophylla Lindl foliage. 1. Effects on intake, digestion and growth by Barbine lambs. Animal. Science., 75(1), 1

Conn, B. J. (2001). "Gmelina - New South Wales Flora Online"

(http://plantnet.rbgsyd.nsw.gov.au/cgibin/NSWfl.pl?- The Plant Information Network System. 2.0. Sydney, Australia: The Royal Botanic Gardens and Domain Trust. Retrieved 13 Mar

El-Mahmood A. M., Doughari, J. H. and Kiman H. S. (2010). In vitro antimicrobial activity of crude leaf and stem bark extracts of Gmelina arborea (Roxb) against some pathogenic species of Enterobacteriaceae. Amino acid content of foods and biological data on proteins. FAO, Rome, Italy: 1(1), 285.

Foo, L. Yeap; Karchesy, Joseph J. (1989). "Chemical Nature of Phlobaphenes". Chemistry and Significance of Condensed Tannins. p. 109. doi:10.1007/978-1-4684-7511-1_6. ISBN 978-1-4684-7513-5.

Giri, M, Divakar, K. Goli, D, Dighe, S. B (2009). Anti ulcer activity of leaves of Gmelina arborea plant in experimentally induced ulcer in Wistar rats. Pharmacologyonline 1(1), 102-10

Halliwell, B.(2007). Dietary polyphenols: good, bad, or indifferent for your health? Cardiovascular Reserach, 73(2), 341-7.

Harbone J.D. (1973) Phytochemical Methods. A Guide to Modern Techniques of Plant Analysis. Chapman and Hall, London.279

Hasan, H.H., I. H. Habib, M. H. Gonaid and M. Islam. (2011). Comparative phytochemical and antimicrobial investigation of some plants growing in Al Jabal Al-Akhdar. Journal of Natural. Products. Plant Resources. 1(1), 1523

Hosny, M. Rosazza, J. P, Gmelinosides, A. L (1998), twelve acylated iridoid glycosides from Gmelina arborea. Journal of Natural Products 61(1) 734-42.

Hyland, B.P.M.; Whiffin, T.; Zich, F. A. (2010). "Home" (http://www.anbg.gov.au/cpbr/cdkeys/rfk/). Australian Tropical Rainforest Plants. Edition 6.1, online version [RFK 6.1]. Cairns, Australia: Commonwealth Scientific and Industrial Research Organisation, through its Division of Plant Industry; the Centre for Australian National Biodiversity Research; the Australian Tropical Herbarium, James Cook University. Retrieved 18th March, 2013.

Kirtikar K.R, Basu B.D (1995). Indian medicinal plant, Dhradhun International Book Distributors. 562

Khan, I. A, Khanum, A. (2005). Herbal therapy for diabetes. Hyderabad: Ukaaz publications; 173 .

Kirtikar K.R, Basu B.D (1999) Indian medicinal plants. Dehradun: International book distributors; 1932-3.

Kulkarni, Y. A, Veeranjaneyulu, A. (2009). Antidiabetic activity of aqueous extract of Gmelina arborea bark in rats. Alternative Theoretical Health Medcine 15(1), 183-4.

Lauridsen, E. B. and Kjaer, (2002). Provenance research in Gmelina arborea Linn, Roxb. Asummary of results freom three decades of research and a discussion of how to use them. International Forestry Review 4(1), 15

Nadkarni, K.M. (2000) Indian materia medica. Mumbai: Popular Prakashan; 1(1),

584-5.

Nayak, B.S, Jen2a, P.K, Dinda, S.C, Ellaiah, P. (2012). Phytochemical investigation and in vitro evaluation of anthelmintic activity of Gmelina arborea roxb. fruit extracts. Asian Journal of Chemistry 24(8), 3445-48.

Nayak, B.S, Jena, P.K, Dinda, S.C, Ellaiah, P. (2011). 
An overview on silviculture and traditional therapeutic uses of Gmnelina arborea Roxb. Journal of Pharmacy Resources 4(5)1

Odebiyi, A and Sofowora A.E (1978).Pythochemical Screening of Nigeria medicinal plant. Part iii Lloydia, 41,234-246

Onwuka G.I (2005). Food analysis and Instrumentation; Theory and Practice. Naphthalic prits Surulere, Lagos Nigeria.219-230

Rajamohamed, M. K. (2013). Chemical scheme of food analysis designed to measure only its basic six components namely, moisture, crude protein, ether extract, crude fibre, Total Ash and Nitrogen free extracts. www.ciba.res.in/books/ciba0178.pdf.

Retrieved April 8th, 2

Rogier (13 July 2012). "A revision of the genus Gmelina (Lamiaceae)" (http://link.springer.com/content/pdf/10.1 007\%2Fs12225-012-9382-4.pdf). Kew Bulletin 67 (3): 293-329.

Sangeeta S, Priyanjali D, Sujata, B, Devasagayam T.P.A.D \& Saroj G. (2006). Bark and Fruit Extracts of Gmelina arborea Protect Liver Cells from Oxidative Stress. International Journal of Pharmaceutical Biology 2006, 44 $(40,237-243$.

Satyanarayana, P, Subramanyam, P. Kasai, R. Tanaka, $O$. (1985). An apiose containing coumarin glycoside from Gmelina arborea.
Phytochemistry 24(1): 1862-3.

Sedgley, M. \& Gardner, J. A. (1990). "International Survey of Underexploited Tropical and Subtropical Perennials with Edible fruits or seed" 26- 30.

Shirwaikar, A. Ghosh, S. Padma, G.M. (2003) Effects of Gmelina arborea Roxb. Leaves on wound healing in rats. Journal of Natural Remedy. 3(1), 45-8

Sofowora, A. (1982). "Medicinal plants and traditional medicine in Africa. John Wiley and sons LTD. 142-146

Tiwari, N. Yadav, A. K, Srivastava, P. Shanker, K. Verma, R.K, Gupta, M. M. (2008). Iridoid glycosides from Gmelina arborea. Phytochemistry 69(1), 2387

US Department of Agriculture, (2013). GRIN Taxonomy for Plants - Gmelina" (http://www.ars-grin.gov/cgi bin/npgs/html/genus.pl 5038). United States Department of Agriculture.

Vogel, A. (2005), "Anthraquinone", Ullmann's Encyclopedia of Industrial Chemistry, Weinheim: Wiley- $\mathrm{VCH}$ doi:10.1002/14356007.a02_347

Vunchi, M.A., A.N. Umar, M. A. King, A.A. Liman, G. Jeremiah and Aigbe, C. O. (2011).

Proximate, vitamins and mineral composition of Vitex doniana (black plum) fruit pulp. Journal of Basic Applied Science 19(1), 97-101. 